\title{
Identification of an osteoclastogenic CD4+ T cell population producing IL-17 and TNF $\alpha$
}

\author{
Thomas Ciucci ${ }^{1}$, Eléonore Birgy-Barelli ${ }^{1}$, Jérôme Pene ${ }^{2}$, Grazia Abou-Ezzi ${ }^{1}$, Nadia Arab ${ }^{3}$, Xavier Hébuterne ${ }^{3}$, \\ Hans Yssel ${ }^{2}$, Claudine Blin-Wakkach', Abdelilah Wakkach ${ }^{1 *}$ \\ From 6th European Workshop on Immune-Mediated Inflammatory Diseases \\ Nice, France. 23-25 November 2011
}

\section{Background}

Crohn's disease is an inflammatory bowel disease (IBD) characterized by an augmentation of activated $\mathrm{T}$ cells and a severe osteopenia due to an increased activity of osteoclasts, the bone-resorbing cells. Osteoclasts result from differentiation of monocytes under the control of two cytokines, RANK-L and M-CSF, produced by bone-forming osteoblasts. Inflammatory cytokines produced by $\mathrm{T}$ cells have been shown to increase osteoclatogenesis, leading to osteopenia. The aim of this study is to identify CD4+ T cells implicated in osteolysis.

\section{Material and methods}

We used a murine model of IBD associated with severe osteopenia, the IL-10-/- mouse to analyze the phenotype and function of bone marrow (BM) CD4+ T cells.

\section{Results}

We showed that CD4+ T cells isolated from the BM of IL10-/- mice with IBD induced in vitro the differentiation of osteoclasts. The analysis in BM of the Th subsets present among these CD4+ T cells revealed, in addition to Th1, a population producing both TNF- $\alpha$ and IL-17, cytokines known to increase osteoclastogenesis. Our results showed that sorted CD4+ IL-17+ TNF $\alpha+\mathrm{T}$ cells increased the production of RANK-L by osteoblasts and induce the differentiation of osteoclasts in vitro. Furthermore, this population led to the recruitment of monocytes (preosteoclasts) in the BM in vivo participating thereby to the increased osteoclastogenesis. Altogether, the induction of RANK-L and monocyte recruitment by CD4+ IL-17+ $\mathrm{TNF} \alpha+\mathrm{T}$ cells may represent a possible mechanism of osteolysis in vivo. Lastly, we found the CD4+ IL-17+

${ }^{1}$ INSERM U576, Nice, France

Full list of author information is available at the end of the article
TNF $\alpha+$ population in the blood of patients with Crohn's disease, but not in controls and experiments are in progress to confirm the osteoclastogenic role of this population in human.

\section{Conclusion}

Altogether, our results showed for the first time that CD4+ IL-17+ TNF $\alpha+$ cells represent an osteoclatogenic T cell subset present in vivo, and potentially responsible for osteopenia in mice and Crohn's patients.

\section{Author details}

${ }^{1}$ INSERM U576, Nice, France. ${ }^{2}$ INSERM U844, Montpellier, France. ${ }^{3}$ Dept. of

Gastroenterology, Hospital I'Archet, Nice, France.

Published: 23 November 2011

doi:10.1186/1479-5876-9-S2-P24

Cite this article as: Ciucci et al:: Identification of an osteoclastogenic

CD4+ T cell population producing IL-17 and TNF $\alpha$. Journal of

Translational Medicine 2011 9(Suppl 2):P24.

Submit your next manuscript to BioMed Central and take full advantage of:

- Convenient online submission

- Thorough peer review

- No space constraints or color figure charges

- Immediate publication on acceptance

- Inclusion in PubMed, CAS, Scopus and Google Scholar

- Research which is freely available for redistribution
C Biomed Central

(C) 2011 Ciucci et al; licensee BioMed Central Ltd. This is an open access article distributed under the terms of the Creative Commons Attribution License (http://creativecommons.org/licenses/by/2.0), which permits unrestricted use, distribution, and reproduction in any medium, provided the original work is properly cited. 